\title{
Antimicrobial Activities of Lactic Acid Bacteria Strains Isolated from Nile Tilapia Intestine (Oreochromis
}

\author{
niloticus)
}

\author{
Ana A. Zapata \\ Instituto de Ecología, Pesquerías y Oceanografía del Golfo de México, Universidad \\ Autónoma de Campeche
}

Av. Agustín Melgar y Juan de la Barrera S/N, Col. Buenavista. C.P. 24039. San Francisco de Campeche, Campeche, México

Tel: 52-(981)-811-9800 ext: 62311 E-mail: atapaz2012@ hotmail.com

\begin{abstract}
Maurilio Lara-Flores (Corresponding author)
Instituto de Ecología, Pesquerías y Oceanografía del Golfo de México, Universidad Autónoma de Campeche
\end{abstract}

Av. Agustín Melgar y Juan de la Barrera S/N, Col. Buenavista. C.P. 24039. San Francisco de Campeche, Campeche, México

Tel: 52-(981)-811-9800 ext: 62311 E-mail: maurilio_lara@yahoo.com.mx

Received: September 20, 2012 Accepted: October 4, 2012

doi:10.5296/jbls.v4i1.2408 URL: http://dx.doi.org/10.5296/jbls.v4i1.2408

\begin{abstract}
The intestinal microflora of Nile tilapia (Oreochromis niloticus) fish was studied to isolate and identify lactic acid bacteria as new probiotic. A total of five lactic acid bacteria were isolated from intestine to evaluate with antibacterial properties. These strains were identified by conventional and molecular techniques as: Enterococcus faecium, Leuconostocmesenteroides, Lactobacillus fermentum, Lactobacillus plantarum, Enterococcus durans. Leuc.mesenteroides present more ability to inhibit growth of fish pathogens bacteria and selected as possible probiotic bacteria to use in aquaculture.
\end{abstract}

Keywords: Probiotic, Antibacterial activity, Nile tilapia, Oreochromis niloticus 


\section{Introduction}

Aquaculture is a fast-growing and rapidly expanding multibillion dollar industry. Marine capture fisheries and aquaculture supplied the world with about 104 million tons of fish in 2004 (FAO, 2007). Of this total, marine aquaculture accounted for about 18\%, where shrimp from aquaculture continues to be the most important commodity traded in terms of value (2.4 million tons). Worldwide, the aquaculture sector has been expanding at an average compounded rate of $9.2 \%$ per year since 1970 , compared to $1.4 \%$ only for capture fisheries and $2.8 \%$ for terrestrial-farmed meat production systems (Lara-Flores, 2011).

With the increasing intensification and commercialization of aquaculture production, disease is a major problem in the fish farming industry (Bondad-Reantaso et al., 2005). It has been well documented that the use of antibiotics develops drug-resistant microorganisms with antibiotic residues retained in fish flesh and environment. In addition, antibiotics can affect the normal microflora of the digestive tract which is beneficial to host and may be inhibited by treatment with the antibiotics (Aly et al., 2008). In this respect, use of probiotic bacteria is a new approach, which is gaining acceptance in aquaculture to control potential pathogens (Alyet al., 2008; Kim and Austin, 2008; Lara-Flores, 2011).

Lactic acid bacteria (LAB) are known microorganisms that have probiotic properties. They can produce inhibitory compounds such as lactic acid, hydrogen peroxide, diacetyl, acetaldehyde and bacteriocin. These compounds are able to inhibit the growth of harmful microorganisms (Ringø and Gatesoupe, 1998; Gatesoupe, 1999). According to many reports, lactic acid bacteria are normal flora in gastrointestinal (GI) tract of healthy animals like mammals and aquaculture animals (Nikoskelainen et al., 2001) with no harmful effects (Ringø et al., 1998). Probiotics improve intestinal microflora and support good health for host by protection against infections by stimulating the immune system, alleviating lactose intolerance, reducing blood cholesterol levels, improving weight gain and feed conversion ratio(Salminen et al., 2004; Lara-Flores and Aguirre-Guzman, 2009; Lara-Flores, 2011).

The present experiment is aimed to isolate lactic acid bacteria as new probiotic from intestine of Nile tilapia (Oreochromis niloticus). Antagonism properties were also investigated to find out high potential probiotic of selected strain to use in fish production.

\section{Materials and Methods}

\subsection{Collection the Samples}

A total of 30 live juvenile Nile tilapia fish were collected from three different farms from Campeche State. The surface of fish bodies were disinfected by alcohol (70\%); dissected under antiseptic conditions; intestines taken out and washed three times with normal saline $(\mathrm{NaCl} 0.85 \%)$. The intestines were then homogenized in $10 \mathrm{ml}$ on sterile saline solution $(\mathrm{NaCl}$ $0.85 \%$ ) whit a mechanic homogenizer (Rengpipat et al., 2008).

\subsection{Isolation of Lactic Acid Bacteria (LAB)}

Using serial dilution, $0.1 \mathrm{ml}$ of homogenized intestine samples were spread on tryptic soy broth (TSB) $\left(\mathrm{DIBICO}^{\mathrm{TM}}\right)$ followed by $48 \mathrm{hrs}$ incubation at $36^{\circ} \mathrm{C}$ (Paludan-Müller et al., 
1999). After pipetting, $0.1 \mathrm{ml}$ of the cultured broth was transferred to $\mathrm{KF}\left(\mathrm{DIFCO}^{\mathrm{TM}}\right)$ and Rogosa agar (DIBICO ${ }^{\mathrm{TM}}$ ) (Badis et al., 2004; Rengpipat et al., 2008). The plates were incubated at $36^{\circ} \mathrm{C}$ for $48 \mathrm{hrs}$. Selected colonies that demonstrated specific morphology to a $\mathrm{LAB}$ were sub-cultured three times on new $\mathrm{KF}$ and Rogosa agar to obtain single colonies (Rengpipat et al., 2008). Gram staining, catalase reaction by $3 \%$ hydrogen peroxide $\left(\mathrm{H}_{2} \mathrm{O}_{2}\right)$ and microscopicmorphology were used for primary identification of the isolates (Kopermsub and Yunchalard, 2010).

\subsection{Identification of the Selected Isolate}

Polymerase Chain Reaction (PCR) method was used to confirm the conventional identification method (Nguyen et al., 2007). DNA of the isolates was extracted according with the method proposed by Karp (1998). PCR was used to amplify the extracted DNAs using primers pAF 5'AGA GTT TGA TCC TGG CTC AG 3'as forward and phR 5'AAG GAG GTG ATC CAG CCG CA 3'as reverse primers (Kopermsub and Yunchalard, 2010) and the products were sequenced (Institute of Biotechnology (IBT-UNAM) using the specific primers, pAF and phR). The sequencing, around $1500 \mathrm{bp}$, were analyzed using MEGA Blast 5 nucleotide sequence software and then compared with the published sequences in GenBank using BLAST software (http://www.ncbi.nlm.nih.gov/blast/) from National Center for Biotechnology Information (NCBI).

\subsection{Pathogens Used to Study Antibacterial Activity of the Isolated LAB}

Four freshwater fish pathogens, Pseudomonas aeroginosaT3, P. putidaT4, Vibrio harveyiT34 and Mycobacterium marinum T217 were used to determine the antibacterial effect of the candidate strains by diffusion and double-layer techniques and commercial LAB for human (L. acidophilus)were used as positive control, obtained from the Microbiology and Molecular Laboratory of Ecology, Fisheries and Oceanography of Gulf of Mexico Institute.

\subsubsection{Diffusion Method}

The pathogenic bacteria were cultured in TSB and incubated at $36^{\circ} \mathrm{C}$ for $24 \mathrm{hrs}$. Thereafter, $10 \mu 1$ of the cultures were spread on tryptic soy agar (TSA) by swab. At the same time, the selected strain was cultured in TSB at $36^{\circ} \mathrm{C}$ for $24 \mathrm{hrs}$. The bacteria were harvested by centrifugation at 13,000 rpm for 2 min and the supernatants were used for antibacterial test using well diffusion methods (Cappuccino and Sherman, 2002; Balcázar et al., 2008).

\subsubsection{Double-layer Method}

The antagonism activity was detected using the double-layer method of Dopazo et al. (1988). Briefly, $50 \mu 1$ of overnight cultures of the LABs in TSB were grown on TSA for $24 \mathrm{hrs}$ at $36^{\circ}$ C. Then, $10 \mu 1$ of overnight culture of the pathogenic strains in TSB were mixed with $5 \mathrm{ml}$ of soft agar at $45^{\circ} \mathrm{C}(1 \%$ of TSA) and were poured over the dish surface; according with Dopazo et al. (1988) at this temperature the bacteria were not affected. The double-layer dishes were incubated at $36^{\circ} \mathrm{C}$ and the inhibition of pathogen growth around and/or over the macrocolony were recorded after $24 \mathrm{hrs}$. 


\section{Results and Discussion}

\subsection{Isolation and Identification of $L A B$}

A total of five of lactic acid bacteria designated as 165, 178, 222, 249 and 252, were isolated from juvenile Nile tilapia fish intestine. The isolates were gram-positive, catalase-negative and short rod or cocobasilli shaped. These strains were selected for identification and further antagonism analysis. The results from the laboratory of IBT-UNAM identified 165 as Leuconostocmesenteroides, 178 as Enterococcus faecium, 222 as Lactobacillus fermentum, 249 as L. plantarum and 252 as E. durans.

These strains were obtained from a previous study (Lara-Flores et al.,2008), which determined the total population and groups of bacteria in Nile tilapia. The authors observed that the lactic acid bacteria were a minor part of microflora in Nile tilapia with less than $7 \%$ of the total count. The same result has been reported by Ringo (1993) and Allameh et al. (2012). For example Ringo (1993) found that 10\% population level of gut microbiota in Artic charr (Salvelinus aplinus L.) was lactic acid bacteria. Though, Ringo et al. (2005) reported the gut microbiota of fish was less diverse than in terrestrial animals, the gastrointestinal tract of fish is not as simple as believed.

\subsection{Antibacterial Activity}

\subsubsection{Diffusion Method}

Results obtained from diffusion method demonstrated that the LAB isolates do not presents any inhibitory effect against fish pathogen bacteria. This could have been because the lactic acid bacteria did not produce inhibitory substances in the culture medium probably because the growing conditions were not appropriate or because there was no competition or a stimulating factor for the production of inhibitory substance. Filho-Lima (2000) mentioned that in many cases the inhibitory substances are produced only in the presence of the pathogen and without this stimulation, inhibitory substances are not produced. Furthermore, Sugita et al.(2007) mentioned that the antibacterial activity can not be studied using only the supernatant of the culture, since the inhibition process involves a variety of factors that are activated at the same time.

\subsubsection{Double-layer Method}

The antimicrobial activity of LAB isolates were tested against fish pathogenic bacteria are summarized in (Table 1) by using double layer assay, and Figure 1illustrates the zones of inhibition against fish pathogenic bacteria under study. The diameters of the inhibition zones were standardized as Light (L) if halo covers less than $10 \%$ of the Petri dish, Medium (M) if halo covers less than $30 \%$ and High if halo covers more than $30 \% . L$. mesenteroides and the commercial probiotic inhibited all the fish pathogenic bacteria with the highest level of inhibition towards Mycobacterium T217 and Pseudomonas T3 (Table 1). A similar frequency of inhibitory bacteria was observed for isolates from halibut larvae (Bergh, 1995), rainbow trout (Brunt and Austin 2005), turbot (Hjelm et al., 2004), shrimp (Rengpipat et al., 1998) and Indian major carps (Ghosh et al., 2007).Allameh et al. (2012) observed a significant 


\section{Macrothink $\underline{\text { Mnstitute }{ }^{\mathrm{tm}}}$}

inhibitory effect of L. mesenteroides against A. hydrophila and S. putrefaciens, all freshwater fish pathogens. In this study we observed a significant inhibitory effect of $L$. mesenteroides to four freshwater fish pathogens different that Allameh et al. (2012) used, thereby confirming the effectiveness of the bacteria to inhibit the growth of fish pathogenic bacteria, and this demonstrates the potential for use as probiotic in fish.

Table 1. Antimicrobial activity of isolates LABS against indicator strain by Dopazo's method in percentage coverage of Petri plate by the LAB

\begin{tabular}{|l|c|c|c|c|c|c|}
\hline \multicolumn{1}{|c|}{$\begin{array}{c}\text { Fish Pathogens } \\
\text { Strains }\end{array}$} & \multicolumn{5}{c|}{ LABS Strains } \\
\hline & Control & $\begin{array}{c}\text { Ent. } \\
\text { faecium }\end{array}$ & $\begin{array}{c}\text { Leuc. } \\
\text { Mesenteroides }\end{array}$ & $\begin{array}{c}\text { L. } \\
\text { fermentum }\end{array}$ & $\begin{array}{c}\text { L. } \\
\text { plantarum }\end{array}$ & $\begin{array}{c}\text { Ent. } \\
\text { durans }\end{array}$ \\
\hline Pseudomonas T3 & 50 & 50 & 30 & 0 & 0 & 10 \\
\hline Pseudomonas T4 & 90 & 0 & 30 & 8 & 0 & 5 \\
\hline Vibrio T34 & 80 & 0 & 90 & 0 & 0 & 5 \\
\hline $\begin{array}{l}\text { Mycobacterium } \\
\text { T217 }\end{array}$ & 40 & 50 & 50 & 0 & 0 & 10 \\
\hline
\end{tabular}

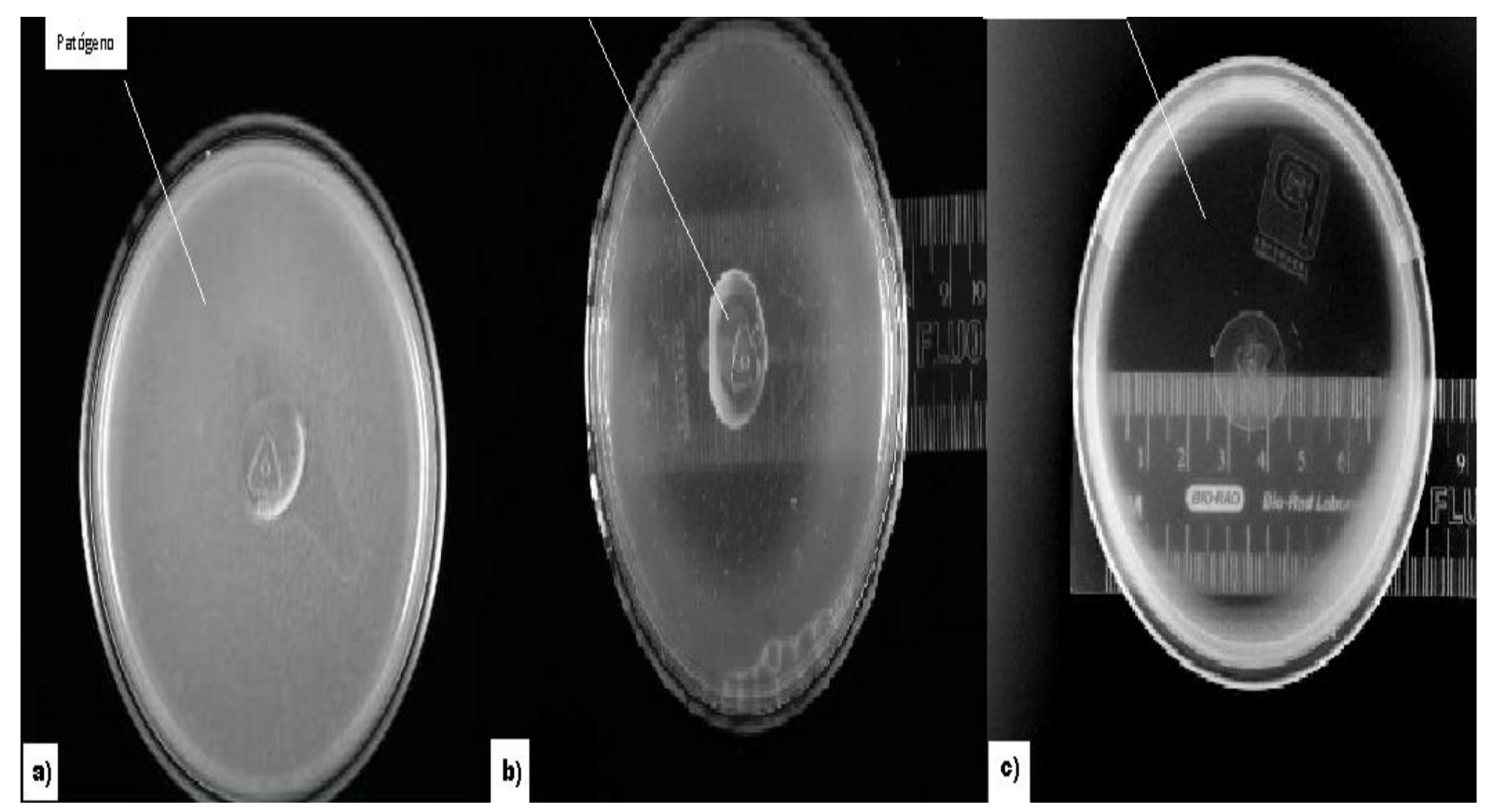

Figure 1. The antimicrobial activity of LAB isolates by using double layer assay. a) Inhibition of Pseudomonas T4 by L. fermentumb) Inhibition of Mycobacterium T217 by control strain c) Inhibition of Vibrio T34 by Leuc.mesenteroides

\section{Conclusions}

The present study concluded that $L$. mesenteroides was normal in microflora in nile tilapia gut. This LAB showed high ability to inhibit growth of freshwater fish pathogen particularly Vibrio sp. and Mycobacterium sp. Therefore, Leuc. mesenteroides has high potential probiotic to use in Nile tilapia culture.

In the opinion of Lara-Flores and Aguirre-Guzman (2009) these specific preparations with beneficial effects for preventing disease and other natural elements are for a stable health in 
the intestinal environment and immune system. The establishment of a strong program of prevention of diseases, which include probiotics and good management, may result in increased production of aquatic organisms. This is one of the purposes of this work, as mentioned above was based on the search for a viable, reliable and low cost alternative to use for control diseases in aquaculture.

\section{References}

Allameh, S. K., Daud, H., Yusoff, F. M., Saad, C. R., \& Ideris, A. (2012). Isolation, identification and characterization of Leuconostocmesenteroidesas a new probiotic from intestine of snakehead fish (Channastriatus). African Journal of Biotechnology, 11, 3810-3816.

Aly, S. M., Ahmed, YA-G., Ghareeb, AA-A., \& Mohamed, M. F. (2008).Studies on Bacillus subtilisand Lactobacillus acidophilus, as potential probiotics, on the immune response and resistance of Tilapia nilótica (Oreochromis niloticus) to challenge infections. Fish Shell Immunology, 25, 128-136. http://dx.doi.org/10.1016/j.fsi.2008.03.013

Badis, A., Guetarni, D., Moussa-Boudjemaa, B., Henni, D. E., Tornadijo, M. E., \& Kihal, M. (2004). Identification of cultivable lactic acid bacteria isolated from Algerian raw goat's milk and evaluation of their technological properties. Food Microbiology, 21, 343-349. http://dx.doi.org/10.1016/S0740-0020(03)00072-8

Balcazar, J. L., Vendrell, D., de Blas, I., Ruiz-Zarzuela, I., Muzquiz, J. L., \& Girones, O. (2008). Characterization of probiotic properties of lactic acid bacteria isolated from intestinal $\begin{array}{llll}\text { microbiota } & \text { of } & \text { fish. } & \text { Aquaculture, }\end{array}$ http://dx.doi.org/10.1016/j.aquaculture.2008.03.014

Bergh, Ø. (1995). Bacteria associated with early life stages of halibut, Hippoglossu hippoglssus L., inhibit growth of a pathogenic Vibrio sp. Journal of Fish Diseases, 18, 31-40. http://dx.doi.org/10.1111/j.1365-2761.1995.tb01263.x

Bondad-Reantaso, M. G., Subasinghe, R. P., Arthur, J. R., Ogawa, K., Chinabut, S., Adlard, R., Tan, Z., \& Shariff, M. (2005). Disease and health management in Asian aquaculture. Veteranary Parasitology, 132, 249-272. http://dx.doi.org/10.1016/j.vetpar.2005.07.005

Brunt, J., \& Austin, B. (2005). Use of a probiotic to control lactococcosis and streptococcosis in rainbow trout, Oncorhynchus mykiss (Walbaum). Journal of Fish Diseases, 28, 693-701. http://dx.doi.org/10.1111/j.1365-2761.2005.00672.x

Cappuccino, J. G., \& Sherman, N. (2002). Microbiology a Laboratory Manual (Vol 1). New York:Benjamin Cumming.

Dopazo, C. P., Lemos, M. L., Lodeiros, C., Bolinches, J., Baria, J. L., \& Toranzo, A. E. (1988). Inhibitory activity of antibiotic-producing marine bacteria against fish pathogens. Journal of AppliedBacterology, $\quad 65, \quad$ 97-101. http://dx.doi.org/10.1111/j.1365-2672.1988.tb01497.x

FAO. (2007). The State of World Fisheries and Aquaculture 2006. Rome:Food and 
Agriculture Organization of United Nations.

Filho-Lima, J. V. M., Vieira, E. C., \& Nicoli, J. R. (2000). Antagonistic effect of Lactobacillus acidophilus, Saccharomyces boulardiiand Escherichia coli combinations against experimental infections with Shigella flexneriand Salmonella enteritidissubsp. typhimuriumin gnotobiotic mice. Journal of Applied Microbiology, 88, 365-370. http://dx.doi.org/10.1046/j.1365-2672.2000.00973.x

Gatesoupe, F. J. (1999). The use of probiotics in aquaculture. Aquaculture, 191, 147-165. http://dx.doi.org/10.1016/S0044-8486(99)00187-8

Ghosh, S., Archana, S., \& Chittaranjan, S. (2007). Isolation of putative probionts from the intestines of Indian major carps. Israeli Journal of Aquaculture, 59, 127-132. http://dx.doi.org/10.1128/AEM.70.12.7288-7294.2004

Hjelm, M., Riaza, A., Formoso, F., Melchiorsen, J., \& Gram, L. (2004). Seasonal incidence of autochthonous antagonistic Roseobacterspp. and Vibronaceaestrains in a turbot larva (Scophthalmus maximus) rearing system. Applied Environmental Microbiology, 70, 7288-7294. http://dx.doi.org/10.1111/j.1472-765X.2008.02401.x

Karp, G. (1998). Biología Celular y Molecular. Mexico: McGraw Hill-Interamericana.

Kim, D. H., \& Austin, B, (2008), Characterization of probiotic carnobacteria isolated from rainbow trout (Oncorhynchus mykiss) intestine. Letters in Applied Microbiology, 47, 141-147.

Kopermsub, P., \& Yunchalard, S. (2010). Identification of lactic acid bacteria associated with the production of plaa-som, a traditional fermented fish product of Thailand. International Journal of Food Microbiology, 138, 200-204.

Lara-Flores, M., Balan-Zetina, S. B., Ramos-Miranda, J., Cú-Escamilla, A. D., \& del Río-Rodríguez, R. E. (2008). Determinación y prevalencia de Mycobacterium spp. en tilapia nilótica (Oreochromis niloticus) cultivada en el municipio de Champotón, Campeche. In: Congreso de Investigación Formativa y Seminarios de Acuacultura y Zootecnia (pp. 19-32).Ciudad Victoria.

Lara-Flores, M., Aguirre-Guzman, G. (2009). The use of probiotic in fish and shrimp aquaculture.A review. In: Perez-Guerra N. \&Pastrana-Castro L. (Eds), Probiotics: Production, evaluation and uses in animal feed (pp. 75-89). Kerala: Research Signpost.

Lara-Flores, M. (2011). The use of probiotic in aquaculture: an overview.International Research Journal of Microbiology, 2, 471-478.

Nguyen, T. F. T., Kang, J. H., \& Lee, M. S. (2007).Characterization of Lactobacillus plantarum $\mathrm{PH} 04$, a potential probiotic bacterium with cholesterol-lowering effects. International Journal of Food Microbiology, 113, 358-361. http://dx.doi.org/10.1016/j.ijfoodmicro.2006.08.015

Nikoskelainen, S., Ouwehand, A., Salminen, S., \& Bylund, G. (2001).Protection of rainbow trout (Oncorhynchus mykiss) from furunculosis by Lactobacillus rhamnosus. Aquaculture, 
198, 229-236. http://dx.doi.org/10.1016/S0044-8486(01)00593-2

Rengpipat, S., Phianphak, W., Piyatiratitivorakul, S., \& Menasveta, P. (1998).Effect of probiotics on Black tiger shrimp Penaeus monodon survival and growth. Aquaculture, 167, 301-313. http://dx.doi.org/10.1016/S0044-8486(98)00305-6

Rengpipat, S., Rueangruklikhit, T., \& Piyatiratitivorakul, S. (2008).Evaluation of lactic acid bacteria as probiotic for juvenile seabass (Latescalcalifer). Aquaculture Research, 39, 134-143. http://dx.doi.org/10.1111/j.1365-2109.2007.01864.x

Ring $\varnothing$, E. (1993). The effect of chromic oxide $\left(\mathrm{Cr}_{2} \mathrm{O}_{3}\right)$ on aerobic bacterial population associated with the intestinal epithelial mucosa of Artic charr, Salvelinusalpinus (L.). Canadian Journal of Microbiology, 39, 1169-1173. http://dx.doi.org/10.1139/m93-177

Ring $\varnothing$, E., Gatesoupe, F. J. (1998). Lactic acid bacteria in fish: a review. Aquaculture, 160, 177-203. http://dx.doi.org/10.1016/S0044-8486(97)00299-8

Ringo, E., Schillinger, U., Holzapfel, W., Naughton, P. J., Pierzynowski, S. G., Zabielski, R., $\&$ Salek, E. (2005). Antimicrobial activity of lactic acid bacteria isolated from aquatic animals and the use of lactic acid bacteria in aquaculture. Biology of Growing Animals, 2, 418-453. http://dx.doi.org/10.1016/S1877-1823(09)70051-7

Salminen, S., Wright, A. V., \& Ouwehad, A. (2004).Lactic acid bacteria (Vol. 1).New York:Marcel Dekker Inc. http://dx.doi.org/10.1201/9780824752033

Sugita, H., Ohta, K., Kuruma, A., \& Tomoko, S. (2007).An antibacterial effect of Lactococcus lactis isolated from the intestinal tract of the Amur catfish, SilurusasotusLinnaesus. $\quad$ Aquaculture $\quad$ Research, $\quad 38, \quad 1-3$. http://dx.doi.org/10.1111/j.1365-2109.2007.01765.x

\section{Copyright Disclaimer}

Copyright reserved by the author(s).

This article is an open-access article distributed under the terms and conditions of the Creative Commons Attribution license (http://creativecommons.org/licenses/by/3.0/). 